Jurnal Ekonomi dan Industri

e-ISSN: $2656-3169$

Volume 22, No.2, Mei-Agustus 2021

p- ISSN: 0853-5248

\title{
PENGARUH PELATIHAN DAN KOMUNIKASI TERHADAP KINERJA KARYAWAN PT. MUSTIKA RATU TBK, CIRACAS JAKARTA TIMUR
}

\author{
Aninda Putri Dewantari 1) \\ 1) Mahasiswa Program Studi Manajemen FE UNKRIS \\ Eddy Sanusi. $\mathbf{S}^{2)}$ \\ 2) Dosen Program Studi Manajemen FE UNKRIS \\ Alamat: Kampus UNKRIS, Jatiwaringin Jakarta Timur \\ Email: eddy.sanusi23@gmail.com
}

\begin{abstract}
The purpose of this study was to determine the training and communication on the performance of employees of PT. Mustika Ratu Tbk Ciracas, East Jakarta. This research is included in the category of causal associative research using a quantitative approach. The population in this study were all employees of PT. Mustika Ratu Tbk Ciracas, East Jakarta, totaling 665 employees, using the slovin formula, obtained a sample of 87 employees. The sampling technique is probability sampling using proportionate stratified random sampling. The research was conducted by distributing questionnaires to respondents, while the research method used simple and multiple linear regression analysis. The results of this study obtained data showing that either partially or simultaneously training and communication have a significant effect on the performance of employees of PT. Mustika Ratu Tbk Ciracas, East Jakarta.
\end{abstract}

Keywords: Training, communication and performance of employees

\section{PENDAHULUAN}

Setiap perusahaan pasti memiliki tujuan untuk mencapai kesuksesan dan juga memajukan perusahaan kearah yang lebih baik. Sumber daya manusia merupakan aspek penting dalam sebuah organisasi, dengan kata lain manusia mempunyai peranan strategis pada suatu organisasi untuk melihat apakah kinerja yang dilakukan manusia bisa mencapai tujuan atau target yang telah ditetapkan. Selain karyawan sebagai pekerja dalam perusahaan, karyawan juga jadi aspek penting dalam perusahaan karena memiliki tenaga, keahlian, kreativitas serta bakat yang dibutuhkan perushaan buat mencapai tujuannya. Karyawan atau pegawai dalam suatu perusahaan membutuhkan pelatihan setiap jangka waktu tertentu.

Pelatihan merupakan faktor penting dalam sebuah perusahaan agar karyawan yang diterima dalam bekerja dapat mengerti tentang prosedur tugas dan tanggung jawab yang diberi kepadanya, dan agar karyawan yang telah bekerja dapat mengetahui serta meningkatkan kemampuan serta keahlian yang dimiliki dalam bekerja. Dengan adanya pelatihan yang baik bagi karyawan baru dan karyawan yang telah bekerja, hasil yang diharapkan perusahaan setelah dilakukan pelatihan dapat membuat karyawan jadi bisa lebih efektif dan efisien dalam melakukan suatu pekerjaan sehingga dapat mencapai sasaran yang udah ditetapkan.

Hal yang sama pentingnya dalam sebuah perusahaan adalah komunikasi. Komunikasi merupakan suatu proses penyampian informasi, dimana sesorang atau beberapa orang, kelompok, organisasi dan masyarakat menciptakan, dan menggunakan informasi agar

This work is licensed under a Creative Commons Attribution-Nomercial-ShareAlike 4.0 International License. Ciptaan disebarluaskan di bawah Lisensi Creative Commons Atribusi-BerbagiSerupa 4.0 Internasional.

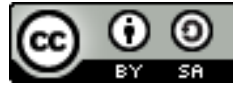


terhubung dengan lingkungan dan orang lain. Komunikasi merupakan aktivitas yang sangat penting didalam kehidupan ini. Komunikasi juga merupakan salah satu faktor paling penting dalam bekerja. Dalam bekerja, tentunya para karyawan akan selalu berkomunikasi satu sama lain, baik dengan atasan, bawahan, maupun dengan rekannya agar enggak terjadinya kesalahpahaman dengan informasi yang didapat. Melihat begitu pentingnya komunikasi, maka komunikasi dapat meningkatkan kinerja karna berkomunikasi menciptakan hubungan yang baik antar karyawan, dengan adanya komunikasi antar karyawan dapat menciptakan hubungan yang baik. Jika kemampuan berkomunikasi baik maka kualitas diri yang dimiliki baik pula. Dan berkomunikasi dapat mencegah kesalahpahaman tentang informasi yang ada, sering kali informasi yang didapat antar karyawan terkadang berbeda, oleh karena itu dengan adanya komunikasi mampu mencegah perbedaan informasi yang diperoleh karyawan tersebut. Komunikasi dalam sebuah perusahan merupakan suatu faktor keberhasilan. untuk membentuk suatu kerjasama setiap anggota perusahaan sangat dibutuhkan sekali komunikasi yang terjalin dengan baik. Komunikasi merupakan dampak faktor keberhasilan suatu perusahaan, komunikasi yang terjalin dengan baik dan efektif dapat memudahkan dalam segala tindakan yang dilakukan oleh seorang pemimpin dalam perusahaan.

Dalam upaya meningkatkan kinerja perusahaan harus memperhatikan faktor-faktor yng memberi pengaruh terhadap kinerja karyawan, maka dari itu pelatihan merupakan upaya perusahaan dalam mengasah dan untuk membantu meningkatkan kinerja, serta komunikasi yang baik berfungsi untuk membangkitkan dan memotivasi karyawan dalam menjalankan suatu pekerjaan.

Tujuan penelitian ini adalah untuk mengetahui pengaruh pelatihan dan komunikasi terhadap kinerja karyawan PT. Mustika Ratu, Tbk Ciracas Jakarta Timur.

\section{LANDASAN TEORI}

\section{Kinerja Karyawan}

Kinerja berasal dari kata job performance atau actual performance yang berarti prestasi kerja atau prestasi yang sesungguhnya dicapai oleh seseorang. Kinerja merupakan hasil atau tingkat keberhasilan seseorang secara keseluruhan selama periode tertentu di dalam melaksanakan tugas dibandingkan dengan berbagai berbagai kemampuan, seperti standar hasil kerja, target atau sasaran atau kriteria yang telah ditentukan terlebih dahulu dan telah disepakati bersama. Menurut Mangkunegara (2017) Kinerja karyawan adalah hasil kerja secara kualitas dan kuantitas yang dicapai oleh seseorang pegawai dalam melaksanakan tugasnya dengan tanggung jawab yang diberikan kepadanya. Menurut Hasibuan (2017) kinerja adalah suatu hasil kerja yang dicapai seseorang dalam melaksanakan tugas-tugas yang dibebankan kepadanya didasarkan atas kecakapan, pengalaman, dan kesungguhan serta waktu. Menurut Sutrisno (2016) mengemukakan bahwa kinerja adalah hasil kerja karyawan dilihat pada aspek kualitas, kuantitas, waktu kerja, tanggung jawab, dan disiplin. Menurut Sedarmayanti (2015) kinerja adalah pencapaian atau prestasi seseorang berkenan dengan tugas yang diberikan kepadanya, hasil kerja yang dicapai oleh seseorang atau sekelompok orang dalam suatu organisasi sesuai dengan wewenang dan tanggung jawab masing-masing dalam upaya mencapai tujuan organisasi bersangkutan secara legal tidak melanggar hukum dan sesuai dengan moral etika.

Menurut Mangkunegara (2017) faktor yang mempengaruhi kinerja diantaranya yaitu : 1). Faktor kemampuan, secara psikologis, kemampuan atau ability pegawai terdiri dari atas

This work is licensed under a Creative Commons Attribution-Nomercial-ShareAlike 4.0 International License. Ciptaan disebarluaskan di bawah Lisensi Creative Commons Atribusi-BerbagiSerupa 4.0 Internasional.

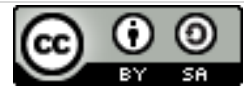


kemampuan potensi (IQ) dan kemampuan realita (pendidikan). 2). Faktor motivasi, motivasi terbentuk dari sikap seorang pegawai dalam menghadapi situasi kerja. Motivasi merupakan kondisi yang menggerakan diri pegawai terarah untuk mencapai tujuan kerja. Sikap mental merupakan kondisi mental yang mendorong seseorang untuk berusaha mencapai potensi kerja secara maksimal.

Indikator kinerja karyawan menurut Mangkuneraga (2017) terdiri dari 1). Kualitas Kerja, menunjukkan kerapihan, ketelitian, keterkaitan hasil kerja dengan enggak mengabaikan volume pekerjaan. Kualitas kerja yang baik dapat menghindari tingkat kesalahan dalam penyelesaian suatu pekerjaan yang dapat bermanfaat bagi kemajuan perusahaan. 2). Kuantitas Kerja, menunjukkan jumlah jenis pekerjaan yang dilakukan dalam satu waktu sehingga efisiensi dan efektivitas dapat terlaksana sesuai dengan tujuan perusahan. 3). Tanggung Jawab, menunjukkan seberapa besarnya pegawai dalam menerima dan melaksanakan pekerjaannya, mempertanggung jawabkan hasil kerja serta sarana dan prasarana yang digunakan dan perilaku kerjanya setiap hari. 4). Kerjasama, kesediaan pegawai untuk berpartisipasi dengan pegawai yang lain secara vertikal dan horizontal baik didalam maupun diluar pekerjaan sehingga hasil pekerjaan akan semakin baik. 5). Inisiatif dari dalam diri anggota perusahaan untuk melakukan pekerjaan serta mengatasi masalah dalam pekerjaan tanpa menunggu perintah dari atasan atau menunjukkan tanggung jawab dalam pekerjaan yang sudah kewajiban seorang pegawai.

\section{Pelatihan}

Pelatihan merupakan sarana paling penting dalam pengembangan sumber daya manusia, melalui pelatihan manajemen organisasi akan memperoleh masukan yang penting dalam menghadapi tantangan di era persaingan, dimana pegawai akan memiliki kemampuan dan keterampilan unik untuk menyelesaikan pekerjaan yang diembannya. Maka pelatihan yang tepat akan mempengaruhi kinerja yang ditampilkan oleh karyawan.

Menurut Rivai (2014) Pelatihan adalah bagian pendidikan yang menyangkut proses belajar untuk memperoleh dan meningkatkan keterampilan diluar sistem pendidikan yang lebih mengutamakan pada praktek dari pada teori. Menurut Sinambela (2016) pelatihan adalah proses pembelajaran yang memungkinkan pegawai melaksanakan pekerjaan yang sekarang sesuai dengan standar perusahaan. Menurut Rachmawati (2008) yang menyatakan bahwa pelatihan merupakan wadah lingkungan bagi karyawan, dimana mereka memperoleh atau mempelajari sikap, kemampuan, keahlian, pengetahuan, dan perilaku spesifik yang berkaitan dengan pekerjaan. Menurut Mondy (2008) mengemukakan bahwa pelatihan merupakan serangkaian aktivitas yang dirancang guna memberi pengetahuan dan keterampilan yang dibutuhkan para pembelajar untuk dapat melaksanakan pekerjaan mereka pada saat ini. Menurut Dessler (2008) yang menyatakan bahwa pelatihan dimaksudkan untuk memberikan keterampilan yang dibutuhkan bagi karyawan baru maupun karyawan yang sudah ada dalam melakukan pekerjaannya.

Menurut Rivai (2014), tujuan dari pelatihan adalah: 1). Untuk meningkatkan kuantitas output. 2). Untuk meningkatkan kualitas output. 3). Untuk menurunkan biaya limbah dan perawatan. 4). Untuk menurunkan jumlah dan biaya terjadinya kecelakaan. 5). Untuk menurunkan turnover, ketidakhadiran kerja serta meningkatkan kepuasan kerja. 6). Untuk mencegah timbulnya antipasti karyawan.

Indikator dari pelatihan yang disampaikan oleh Rivai, (2014) meliputi: 1). Materi Pelatihan, dengan mengetahui kebutuhan akan pelatihan, sebagai hasil dari langkah pertama dapat ditentukan materi yang harus diberikan. 2). Metode Pelatihan, sesuai dengan materi

This work is licensed under a Creative Commons Attribution-Nomercial-ShareAlike 4.0 International License. Ciptaan disebarluaskan di bawah Lisensi Creative Commons Atribusi-BerbagiSerupa 4.0 Internasional.

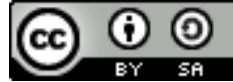


pelatihan yang diberikan, maka ditentukanlah metode atau cara penyajian yang paling tepat. Penentuan atau pemilihan metode pelatihan tersebut didasarkan atas materi yang akan disajikan. 3). Pelatih (Instruktur), pelatih harus didasarkan pada keahlian dan kemampuannya untuk mentranformasikan keahlian tersebut pada peserta pelatihan. 4). Peserta Pelatihan, agar program pelatihan dapat mencapai sasaran hendaknya para peserta dipilih yang benar-benar siap dilatih artinya mereka tenaga kerja yang diikutsertakan dalam pelatihan adalah mereka yang secara mental telah dipersiapkan untuk mengikuti program tersebut. Pada langkah ini selalu dijaga agar pelaksanaan kegiatan pelatihan benar-benar mengikuti program yang telah ditetapkan 5). Sarana Pelatihan, sarana pendukung evaluasi pelatihan untuk mengukur kelebihan suatu program, kelengkapan, dan kondisi yang merupakn umpanbalik u/menilai atau menhasilkan output yang sesuai.

\section{Komunikasi}

Komunikasi (bahasa inggris: Communication) berasal dari bahasa latin Communis yang berarti "sama" atau Communico, Communocatio, atau Communicare yang berarti "membuat sama" (bahasa inggris: make to common). Secara sederhana komunikasi dapat terjadi apabila ada kesamaan antara penyampaian pesan dan orang yang menerima pesan. Selain itu, definisi lain komunikasi adalah pengiriman dan penerimaan pesan atau berita antara dua orang atau lebih sehingga pesan yang dimaksud dapat dipahami. Sedangkan kajian komunikasi adalah suatu disiplin akademis yang mempelajari proses komunikasi manusia.

Menurut Suranto (2011) Komunikasi dikatakan efektif apabila dalam suatu proses komunikasi itu, pesan yang disampaikan seorang komunikator dapat diterima dan dimengerti oleh komunikan, persis seperti yang dikehendaki oleh komunikator berhasil menyampaikan pesan yang berhasil menyampaikan pesan yang dimaksudnya, sedangkan komunikan berhasil menerima dan memahaminya. Menurut Carapeboka (2017) komunikasi merupakan proses penyampaian pesan oleh komunikator kepada komunikan yang didalamnya juga terkandung pesan-pesan dan makna tertentu. Menurut Mangkunegara (2017) mengemukakan bahwa komunikasi dapat diartikan sebagai proses pemindahan suatu informasi, ide, pengertian dari seseorang kepada orang lain dengan harapan orang lain tersebut dapat menginterpretasikannya sesuai dengan tujuan yang dimaksud. Dan menurut Sinambela (2016) menyatakan bahwa komunikasi adalah suatu proses pembentukan, penyampaian, penerimaan, dan pengelolaan pesan yang terjadi di dalam diri seseorang dan/atau diantara dua atau lebih dengan tujuan tertentu. Menurut Usman (2014) komunikasi adalah proses penyampaian atau penerimaan pesan dari satu orang kepada orang lain, baik langsung maupun tidak langsung, secara tertulis, lisan maupun bahasa nonverbal.

Menurut Suranto (2011) Tujuan komunikasi itu bermacam-macam, beberapa diantaranya sebagai berikut: 1). Mengungkapkan perhatian kepada orang lain. 2). Menemukan diri sendiri. 3). Menemukan dunia luar. 4). Membangun dan memelihara hubungan yang harmonis. 5). Mempengaruhi sikap dan tingkah laku. 6). Mencari kesenangan atau sekedar menghabiskan waktu. 7). Menghilangkan kerugian akibat salah komunikasi. 8). Memberi bantuan (konseling).

Menurut Suranto, (2011), indikator dari komunikasi adalah sebagai berikut: 1). Pemahaman, ialah kemampuan memahami pesan secara cermat sebagaimana dimaksud oleh komunikator. Tujuan komunikasi adalah terjadinya pengertian bersama, dan untuk sampai pada tujuan itu, maka seorang komunikator maupun komunikan harus bersama-sama saling mengerti fungsinya masing-masing. Komunikator mampu menyampaikan pesan sedangkan komunikan mampu menerima pesan yang disampaikan oleh komunikator.

2). Kesenangan, apabila

This work is licensed under a Creative Commons Attribution-Nomercial-ShareAlike 4.0 International License. Ciptaan disebarluaskan di bawah Lisensi Creative Commons Atribusi-BerbagiSerupa 4.0 Internasional.

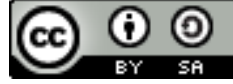


proses komunikasi itu selain berhasil menyampaikan informasi, juga dapat berlangsung dalam suasana yang menyenangkan kedua belah pihak. Suasana yang lebih menyenangkan akan lebih nyaman untuk berinteraksi bila dibandingkan dengan suasana yang tegang, karna komunikasi bersifat fleksibel. Dengan adanya suasana seperti itu, maka akan timbul kesan yang menarik. 3). Pengaruh pada sikap, tujuan berkomunikasi adalah untuk mempengaruhi sikap. Jika dengan berkomunikasi dengan orang lain, kemudian terjadi perubahan pada perilakunya, maka komunikasi yang terjadi adalah efektif, dan jika tidak ada perubahan pada sikap seseorang maka komunikasi tersebut tidaklah efektif. 4). Hubungan yang semakin baik, bahwa dalam proses komunikasi yang efektif secara tidak sengaja meningkatkan kadar hubungan interpersonal. Seringkali jika orang telah memiliki persepsi yang sama, kemieipan karakter, cocok, dengan sendirinya hubungan akan terjadi dengan baik. 5). Tindakan, komunikasi akan efektif jika kedua belah pihak setelah berkomunikasi terdapat adanya sebuah tindakan. Seseorang biasanya akan cenderung lebih tertarik dengan orang lain karna memiliki faktor kesamaan (sama hobi, sama sifat), keakraban (keluarga, teman, karib), dan kesukaan. Dengan kondisi seperti ini orang enggak merasa sungkan untuk bicara, yakni menceritakan masalah hidupnya secara jujur tanpa adanya kecanggungan berkomunikasi diantara keduanya. Jika sudah demikian, maka antara satu dengan yang lainnya akan saling mempengaruhi dan dengan sendirinya komunikasi akan langsung secara efektif. Komunikasi efektif menuntut kepekaan seseorang dalam situasi dan kondisi yang ada, bahkan telah banyak kegagalan organisasi dikaitkan dengan komunikasi yang buruk. Masalah yang paling sulit dalam komunikasi adalah bagaimana cara mendapatkan perhatian dari para pendengar untuk memastikan bahwa mereka mendengarkan.

\section{METODE PENELITIAN}

Penelitian ini termasuk dalam kategori penelitian asosiatif kausal dengan menggunakan pendekatan kuantitatif. Populasi pada penelitian ini adalah keseluruhan karyawan PT. Mustika Ratu Tbk Ciracas, Jakarta Timur yang berjumlah 665 karyawan, dengan menggunakan rumus slovin, maka didapat sampel sebanyak 87 karyawan. Teknik pengambilan sample adalah probability sampling dengan menggunakan proportionate stratified random sampling. Menurut Sugiyono (2018) proportionate stratified random sampling adalah teknik yang digunakan apabila populasi mempunyai anggota/unsur yg tidak homogen dan berstrata secara proporsional. Penelitian dilakukan dengan menyebarkan kuesioner kepada responden sejumlah 87 karyawan, sedangkan metode penelitian dengan menggunakan analisis regresi linear sederhana dan berganda.

\section{HASIL PENELITIAN DAN PEMBAHASAN}

\section{Hasil Penelitian}

\section{Uji instrumen data}

This work is licensed under a Creative Commons Attribution-Nomercial-ShareAlike 4.0 International License. Ciptaan disebarluaskan di bawah Lisensi Creative Commons Atribusi-BerbagiSerupa 4.0 Internasional.

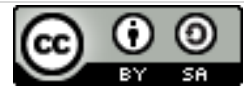


Untuk dapat menentukan bahwa pelatihan dan komunikasi dapat dijadikan pengukur terhadap kinerja karyawan PT. Mustika Ratu, Tbk Ciracas Jakarta Timur. Namun sebelumnya data diolah terlebih dahulu dan dilakukan pengujian terhadap varibel yang digunakan yaitu pelatihan dan komunikasi dan kinerja karyawan untuk mengetahui data tersebut akurat dan dapat dipercaya.

\section{Uji validitas}

Pengujian validitas ini dilakukan untuk menguji apakah tiap butir pernyataan telah mewakili indikator yang akan diteliti, persyaratan minimum untuk dapat dikatakan valid adalah $\mathrm{r}=0,30$. Jadi, apabila korelasi antara butir-butir item pernyataan dengan skor total kurang dari 0,30, maka butiran dalam instrumen tersebut dapat dikatakan tidak valid. Uji validitas dilakukan dengan melihat korelasi antara skor masing-masing item pernyataan dengan skor total. (Sugiyono, 2018).

Dari perhitungan koefisien korelasi skor tiap butir pernyataan instrumen dari 87 responden tentang pelatihan dengan jumlah 14 butir pernyataan; instrumen komunikasi 14 butir pernyataan dan instrumen kinerja karyawan 10 butir pernyataan dengan total skor setiap responden diperoleh hasil $r$ hitung lebih besar dari $r$ kritis 0,30 . maka seluruh item pernyataan didapatkan hasil yang valid.

\section{Uji reabilitas}

Tabel 1: Hasil Uji Reabilitas

\begin{tabular}{lcc}
\hline \multicolumn{1}{c}{ Variabel } & Cronbach's Alpha & R kritis \\
\hline Pelatihan & 0,880 & 0,60 \\
Komunikasi & 0,818 & 0,60 \\
Kinerja Karyawan & 0,839 & 0,60 \\
\hline
\end{tabular}

Dasar pengambilan keputusan jika nilai Cronbach Alpha $>0.60$ maka datanya realibel tapi jika Conbach Alpha $<0.60$ maka datanya tida reliabel. Pada hasil penilitian ini nilai Cronbach Alpha pelatihan 0,880 >0.60; komunikasi $0.818>0.60$, dan kinerja $0.839>0.60$ maka data dinyatakan reliabel.

\section{Analisis regresi linear sederhana}

Tabel 2: Pengaruh Pelatihan Terhadap Kinerja Karyawan PT. Mustika Ratu, Tbk Ciracas Jakarta Timur

\section{Variabel}

\section{Parameter}




\begin{tabular}{ccccccc}
\hline & $\mathbf{R}$ & $\begin{array}{c}\text { R } \\
\text { Square }\end{array}$ & Konstanta & $\begin{array}{c}\text { Koefisien } \\
\text { Regresi }\end{array}$ & Sig. & $\boldsymbol{\alpha}$ \\
\hline Pelatihan 0.506 & 0.256 & 19.202 & 0.373 & 0.000 & 0.01 \\
\hline Pengujian Signifikansi & & & & & \\
\hline \multicolumn{2}{l}{ t hitung > t tabel $=5.406>1.988$} \\
\hline
\end{tabular}

Keterangan : Variabel Kinerja Karyawan

Sumber: data diolah 2021

Berdasarkan Tabel 2, nilai koefisien determinasi $\left(\mathrm{R}^{2}\right)$ sebesar 0.256 , artinya pelatihan memberikan kontribusi sebesar 25,6\% terhadap kinerja karyawan PT. Mustika Ratu, Tbk Ciracas Jakarta Timur. sedangkan sisanya sebesar 74,4\% disumbangkan faktor lain.

$$
\text { Persamaan regresi : } \mathrm{Y}=19.202+0,373 \mathrm{X}_{1}
$$

Pelatihan berpengaruh positif dan signifikan pada tingkat nyata $99 \%$ terhadap kinerja karyawan PT. Mustika Ratu, Tbk Ciracas Jakarta Timur. Koefisien pelatihan sebesar 0,373, artinya jika ada peningkatan pelatihan, maka kinerja karyawan PT. Mustika Ratu, Tbk Ciracas Jakarta Timur akan meningkat. Nilai t hitung $=5,406$ lebih besar dari $\mathrm{t}$ tabel $=1,988$, hal ini berarti pelatihan berpengaruh positif dan signifikan terhadap kinerja karyawan PT. Mustika Ratu, Tbk Ciracas Jakarta Timur.

Tabel 3: Pengaruh Komunikasi Terhadap Kinerja Karyawan PT. Mustika Ratu, Tbk Ciracas Jakarta Timur

\begin{tabular}{ccccccc}
\hline \multirow{2}{*}{ Variabel } & $\mathbf{R}$ & $\begin{array}{c}\mathbf{R} \\
\text { Square }\end{array}$ & Konstanta & $\begin{array}{c}\text { Koefisien } \\
\text { Regresi }\end{array}$ & Sig. & $\boldsymbol{\alpha}$ \\
\hline Komunikasi & 0.569 & 0.324 & 14.638 & 0.498 & 0.000 & 0.01 \\
\hline Pengujian Signifikansi & & & & \\
\hline t hitung $>$ t tabel $=6.381>1.988$ & & & & \\
\hline Ke
\end{tabular}

Keterangan : Variabel Kinerja Karyawan

Sumber: data diolah 2021

Berdasarkan Tabel 3, nilai koefisien determinasi $\left(\mathrm{R}^{2}\right)$ sebesar 0.569 , artinya komunikasi memberikan kontribusi sebesar 56,9\% terhadap kinerja karyawan PT. Mustika Ratu, Tbk Ciracas Jakarta Timur. sedangkan sisanya sebesar 43,1\% disumbangkan faktor lain.

$$
\text { Persamaan regresi : } \mathrm{Y}=14.638+0,498 \mathrm{X}_{2}
$$

Komunikasi berpengaruh positif dan signifikan pada tingkat nyata 99\% terhadap kinerja karyawan PT. Mustika Ratu, Tbk Ciracas Jakarta Timur. Koefisien komunikasi sebesar 0,498, artinya jika ada peningkatan komunikasi, maka kinerja karyawan PT. Mustika Ratu, Tbk Ciracas Jakarta Timur akan meningkat. Nilai $\mathrm{t}$ hitung $=6,381$ lebih besar dari $\mathrm{t}$ tabel $=1,988$, hal ini berarti komunikasi berpengaruh positif dan signifikan terhadap kinerja karyawan PT. Mustika Ratu, Tbk Ciracas Jakarta Timur.

\section{Analisis regresi linear berganda}

This work is licensed under a Creative Commons Attribution-Nomercial-ShareAlike 4.0 International License. Ciptaan disebarluaskan di bawah Lisensi Creative Commons Atribusi-BerbagiSerupa 4.0 Internasional. 
Tabel 4: Pengaruh Pelatihan dan Komunikasi Terhadap Kinerja Karyawan PT. Mustika Ratu, Tbk Ciracas Jakarta Timur

\begin{tabular}{lcccccc}
\hline \multirow{2}{*}{ Variabel } & \multicolumn{6}{c}{ Parameter } \\
\cline { 2 - 7 } & Mult. R & $\begin{array}{c}\text { R } \\
\text { Square }\end{array}$ & Konstanta & $\begin{array}{c}\text { Koefisien } \\
\text { Regresi }\end{array}$ & Sig. & $\boldsymbol{\alpha}$ \\
\hline Pelatihan & 0,648 & 0,420 & \multirow{2}{*}{6,035} & 0,248 & 0,000 & 0 \\
Komunikasi & 0,01 & 0,384 & 0,000 & 0.01 \\
\hline Pengujian Signifikan & & & & 0,000 & \\
\hline \multicolumn{2}{l}{ F hitung > F tabel = 30,400 > 3,105 } & & & & \\
\hline
\end{tabular}

Keterangan: Variabel Kinerja

Sumber: data diolah 2021

Berdasarkan Tabel 4, nilai F hitung sebesar 30,400 dibadingkan dengan F tabel sebesar 3,105 , artinya secara bersama-sama pelatihan dan komunikasi berpengaruh signifikan pada tingkat nyata 99\% terhadap kinerja karyawan PT. Mustika Ratu, Tbk Ciracas Jakarta Timur. Nilai Koefisien Determinasi $\left(\mathrm{R}^{2}\right)$ sebesar 0.420 , artinya pelatihan dan komunikasi memberikan kontribusi sebesar 42,0\% kepada kinerja karyawan PT. Mustika Ratu, Tbk Ciracas Jakarta Timur, sedangkan sisanya sebesar 58,0\% disumbangkan faktor lain yang tidak dibahas dalam penelitian ini.

$$
\text { Persamaan regresi } \mathrm{Y}=6,035+0,248 \mathrm{X}_{1}+0,384 \mathrm{X}_{2}
$$

Pelatihan dan komunikasi berpengaruh signifikan terhadap kinerja karyawan PT. Mustika Ratu, Tbk Ciracas Jakarta Timur, pada tingkat nyata 95\%. Koefisien pelatihan sebesar 0,248 artinya jika ada peningkatan pelatihan, maka kinerja karyawan PT. Mustika Ratu, Tbk Ciracas Jakarta Timur, akan meningkat dengan asumsi komunikasi tidak berubah. Koefisien komunikasi sebesar 0,384, artinya jika ada peningkatan komunikasi, maka kinerja karyawan PT. Mustika Ratu, Tbk Ciracas Jakarta Timur, akan meningkat dengan asumsi pelatihan tidak berubah.

\section{Pembahasan}

\section{Pengaruh Pelatihan Terhadap Kinerja Karyawan PT. Mustika Ratu, Tbk Ciracas Jakarta Timur}

Hasil penelitian menunjukan bahwa pelatihan mendukung peningkatan kinerja karyawan PT. Mustika Ratu, Tbk Ciracas Jakarta Timur. Hal ini menunjukkan bahwa materi pelatihan sudah yang terbaru, cukup lengkap, memadai dan dapat dipahami oleh para peserta, dapat memberikan manfaat secara pengetahuan, keterampilan, metode pelatihan cukup menarik, sudah tepat, sesuai yang diinginkan perusahaan, pelatih dapat menyampaikan materi dengan baik, dapat memotivasi peserta, dapat mengajarkan dengan jelas, pelatih dapat menguasai materi dengan baik, memiliki kepribadian baik, peserta memiliki kualitas, sudah diseleksi terlebih dahulu oleh perusahaan, fasilitas pelatihan sudah cukup lengkap dan mamadai, serta ruang yang digunakan dalam pelatihan bersih sehingga membuat nyaman. Hasil dari penelitian ini dapat diperkuat dan didukung dengan penelitian terdahulu yang dilakukan oleh Fachtur, et al (2019), Marpaung, et al (2020), Septian (2015), Falola, et al (2014), Farooq dan Khan (2011), dan Swies et al (2019) yang menyatakan bahwa pelatihan berperngaruh positif dan signifikan terhadap kinerja karyawan, maka hipoteis pertama dapat diterima.

This work is licensed under a Creative Commons Attribution-Nomercial-ShareAlike 4.0 International License. Ciptaan disebarluaskan di bawah Lisensi Creative Commons Atribusi-BerbagiSerupa 4.0 Internasional.

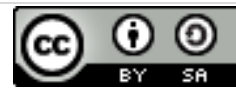




\section{Pengaruh Komunikasi Terhadap Kinerja Karyawan PT. Mustika Ratu, Tbk Ciracas Jakarta Timur}

Hasil penelitian menunjukan bahwa komunikasi mendukung peningkatan kinerja karyawan PT. Mustika Ratu, Tbk Ciracas Jakarta Timur. Hal ini menunjukkan bahwa karyawan mampu mendengarkan informasi yang diberikan sesama rekan kerja maupun dengan atasan, mampu memberikan respon dan umpan balik terhadap informasi yang diberikan, merasa senang saat berkomunikasi dengan atasan atau rekan kerja, atasan dapat memberikan perintah dalam keadaan yang stabil, dapat memberikan pengaruh terhadap perubahan sikap, mampu menghargai pendapat sesama rekan kerja maupun atasan, dapat menerima kritikan, hubungan dengan rekan kerja dan atasan terjalin dengan baik, segera memperbaiki kesalahan apabila mendapat kritikan, memahami pesan dan melakukan tindakan sesuai isi pesan, serta segera melaksanakan perintah yang diberikan. Hasil penelitian ini dapat diperkuat dengan penelitian yang telah dilakukan sebelumnya oleh Purwanto (2013), Fachtur, et al (2019), Marpaung, et al (2020), Priyambodo dan Nugraha (2019), Safitri dan Patrisia (2018), dan Jamilus dan Heriyanto (2019) yang menyatakan bahwa komunikasi memiliki pengaruh positif sdan ignifikan terhadap kinerja karyawan. maka hipoteis kedua dapat diterima.

\section{Pengaruh Secara Simultan Pelatihan dan Komunikasi Terhadap Kinerja Karyawan PT. Mustika Ratu, Tbk Ciracas Jakarta Timur}

Berdasarkan hasil analisis diketahui bahwa pelatihan dan komunikasi dapat mendukung peningkatan kinerja karyawan PT. Mustika Ratu, Tbk Cirakas Jakarta Timur. Hasil penelitian ini juga didukung dan diperkuat oleh penelitian yang sudah dilakukan oleh Fatchur, et al (2019), dan Marpaung, et al (2020) yang menyatakan bahwa pelatihan dan komunikasi memiliki pengaruh positif dan signifikan terhadap kinerja karyawan, maka hipoteis ketiga dapat diterima.

\section{KESIMPULAN DAN SARAN}

\section{Kesimpulan}

Berdasarkan penelitian yang dilakukan, maka dapat disimpulkan sebagai berikut: 1). Pelatihan mendukung peningkatan kinerja karyawan PT. Mustika Ratu, Tbk Ciracas Jakarta Timur. 2). Komunikasi mendukung peningkatan kinerja karyawan PT. Mustika Ratu, Tbk Ciracas Jakarta Timur. 3). Pelatihan dan komunikasi mendukung peningkatan kinerja karyawan PT. Mustika Ratu, Tbk Ciracas Jakarta Timur.

\section{Saran}

Berdasarkan kesimpulan yang telah dikemukakan diatas maka peneliti berusaha memberikan saran yang mungkin dapat dijadikan masukan bagi pihak-pihak terkait atau pihakpihak yang berkepentingan supaya dapat dipertimbangkan, saran yang dapat peneliti sampaikan yaitu: 1). Kinerja karyawan melalui indikator kualitas kerja yang memberikan nilai terendah dalam pembentukan kinerja karyawan, maka perusahaan harus mempunyai strategi untuk mencapai standar kualitas kerja yang telah ditetapkan dalam perusahaan serta memberikan pembinaan terus-menerus secara keseimbangan. 2). Pelatihan melalui indikator materi pelatihan yang memberikan nilai terendah dalam pembentukan variabel pelatihan, dimana perusahaan harus lebih memikirkan lagi materi-materi yang diberikan saat pelatihan dan membuat materi

This work is licensed under a Creative Commons Attribution-Nomercial-ShareAlike 4.0 International License. Ciptaan disebarluaskan di bawah Lisensi Creative Commons Atribusi-BerbagiSerupa 4.0 Internasional.

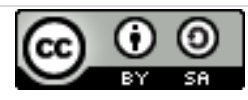


pelatihan lebih menarik lagi agar para peserta pelatihan dapat menjalankan pelatihan dengan nyaman sehingga dapat meningkatkan kinerja karyawan. 3). Komunikasi melalui indikator kesenangan yang memberikan nilai terendah dalam pembentukan komunikasi, maka dalam berkomunikasi satu sama lain baik sesama rekan kerja maupun kepada atasan harus terjalin dengan baik. Oleh karna itu atasan dapat memberikan arahan atau nasihat kepada bawahan melalui komunikasi yang baik, serta sesama rekan kerja harus menciptakan dan menjalin hubungan yang baik sehingga dapat menciptakan suasana nyaman dalam bekerja sehingga dapat meningkatkan kinerja karyawan.

\section{DAFTAR PUSTAKA}

Carapeboka, Ratu Mutilaela. 2017. Konsep dan Ilmu Komunikasi. Yogyakarta: Andi.

Dessler, Gary.2008. Manajemen Sumber Daya Manusia. Jakarta: PT. Indeks

Falola, H. O., Osibanjo, A. O., \& Ojo, S. I. 2014. Effectiveness Of Training And Development On Employees' Performance And Organisation Competitiveness In The Nigerian Banking Industry. Bulletin of the Transilvania University of Braşov Series V: Economic Sciences - Vol. 7 (56) No. 1 - 2014 , 7, 56.

Farooq, M., \& Khan, D. A. 2011. Impact of Training and Feedback on Employee Performance. Far East Journal of Psychology and Business Vol. 5 No. 1 Oct. 2011, 5.

Fatchur, M. R.A., Fattah, Abdul dan Istanti, Enny. 2019. Pengaruh Pelatihan, Komunikasi, dan Lingkungan Kerja Terhadap Kinerja Karyawan PT. Home Center Indonesia East Coast Mall Surabaya". Jurnal Manajemen Branchmark. Vol. 3 Issue 3, 2017 hal. 608-619.

Hasibuan, Malayu S.P. 2017. Manajemen Sumber Daya Manusia. Jakarta: PT. Bumi Aksara.

Jamilus, dan Heryanto. 2019. The Effect of Competence, Communication \& Motivation on Employee Performance in People's Welfare Regional Secretariat of Padang City, Indonesia. Archives of Business Research-Vol.7, No.5 Publication Date: May. 25, 2019, 7.

Mangkunegara, Anwar Prabu. 2017. Manajemen Sumber Daya Manusia Perusahaan, Cetakan Kesepuluh, Bandung: PT. Remaja Rosdakarya.

Marpaung, F. K., Namirah, Y., Usandra, S., Putra, G., \& Monica, C. 2020. Pengaruh Komunikasi, Pelatihan dan Kepuasan Kerja Terhadap Kinerja Karyawan Pada PT Globelink Sea And Air Freight Indonesia. Jurnal Warta Edisi 63, Volume 14, Nomor 1: 1-208, 14, 1-208.

Mondy, Wayne. 2008. Manajemen Sumber Daya Manusia. Jilid 1. Jakarta: Erlangga.

Priyambodo, A., dan Nugraha, A. 2019. The Influence of Work Discipline, Coordination, and Communication on Employee Performance at the Curug Flight Facility Calibration Center In Tangerang Indonesia. Ilomata International Journal of Social Science P-ISSN: 2714898X; E-ISSN: 2714-8998 Vol. 1 No. 1 October 2019 page:35-42, 1, 35-42.

Purwanto, S. B. 2013. Pengaruh Komunikasi, Motivasi dan Kepuasan Kerja terhadap Kinerja Karyawan (Studi pada Proyek Pondasi Tower di Timor Leste PT Cahaya Inspirasi Indonesia). Jurnal Aplikasi Manajemen | Volume 11 | Nomor 1 | Maret 2013 , 11.

Rachmawati, Ike Kusdyah, 2008, Manajemen Sumber Daya Manusia. Yogyakarta: Penerbit ANDI.

This work is licensed under a Creative Commons Attribution-Nomercial-ShareAlike 4.0 International License Ciptaan disebarluaskan di bawah Lisensi Creative Commons Atribusi-BerbagiSerupa 4.0 Internasional.

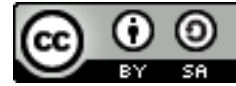


Rivai, Veithzal, 2014. Manajemen Sumber Daya Manusia untuk Perusahaan : dari Teori Ke Praktik, Edisi Pertama, Depok: Penerbit PT. Raja Grafindo Persada.

Safitri, S. R., dan Patrisi, D. 2018. The Effect of Leadership, Communication, and Motivation On Employee Performance: A Literature Review. Advances in Economics, Business and Management Research, volume 64.

Sedarmayanti. 2015. Manajemen Sumber Daya Manusia. Bandung: PT. Refika Aditama.

Septiani, V. M. 2015. PENGaruh Pelatihan, Pengalaman Kerja, dan Promosi Jabatan Terhadap Kinerja Karyawan Pada Badan Pemeriksa Keuangan Republik Indonesia Perwakilan Sulawesi Utara. Jurnal EMBA Vol.3 No.3 Sept. 2015, Hal.992-1002, 3, 992-1002.

Sinambela. Lijan Poltak. 2016. Manajemen Sumber Daya Manusia: Membangun Tim Kerja yang Solid untuk Meningkatkan Kinerja. Jakarta: Bumi Aksara.

Sugiyono. 2018. Statikstika Untuk Penelitian. Bandung: Alfabeta.

Suranto, AW. 2011. Komunikasi Interpersonal. Yogyakarta : Graha Ilmu.

Sutrisno, Edy 2016, Manajemen Sumber Daya Manusia, Cetakan Kedelapan, Jakarta: Prenamedia Group

Swies, R. J., Ghalion, R., El-Mashaleh, M., Amayreh, I., Niveen, A.-S., \& Balkhi, W. A. 2019. The Effects Of Training and Motivating Employees on Improving Performance of Construction Companies: The Case Of Jordan. International Journal of Information, Business and Management, Vol. 11, No.2, 2019, 2.

Usman, Husaini. 2014. Manajemen Teori, Praktik, dan Riset Pendidikan.Yogyakarta: Bumi Aksara.

This work is licensed under a Creative Commons Attribution-Nomercial-ShareAlike 4.0 International License. 